\title{
Treatment of Girolando cattle dermatophilosis using a combination of different plant extracts in the municipality of Abomey-Calavi, Republic of Benin
}

\author{
Camus Adoligbe ${ }^{1}$, Ricoland Gangbe ${ }^{1}$, Justin Adinci ${ }^{1}$, Samuel Mantip ${ }^{2}$ iD and Souaïbou Farougou ${ }^{1}$ (D)
}

1. Research Unit on Communicable Diseases, Polytechnic School of Abomey-Calavi, University of Abomey-Calavi, Cotonou, 01BP 2009, Benin; 2. Virology Division, National Veterinary Research Institute. PMB 0001, Vom, Nigeria. Corresponding author: Camus Adoligbe, e-mail: adolcam83@yahoo.fr

Co-authors: RG: gangbejosias@gmail.com, JA: adincijustin@gmail.com, SM: samuelmantip5@gmail.com, SF: farougou@gmail.com

Received: 11-04-2021, Accepted: 06-10-2021, Published online: 25-10-2021

doi: www.doi.org/10.14202/vetworld.2021.2750-2756 How to cite this article: Adoligbe C, Gangbe R, Adinci J, Mantip S, Farougou S (2021) Treatment of Girolando cattle dermatophilosis using a combination of different plant extracts in the municipality of Abomey-Calavi, Republic of Benin, Veterinary World, 14(10): 2750-2756.

\begin{abstract}
Background and Aim: Dermatophilosis is a bacterial infection of the skin of animals. It is prevalent worldwide and is caused by Dermatophilus congolensis. The study aimed to assess the therapeutic efficacy of different mixtures prepared with indigenous phytogenetic extracts from Benin in the management and treatment of Girolando cattle that showed high sensitivity to the disease compared to any other known cattle breed in Benin.

Materials and Methods: Consequently, two types of extract mixtures (extract mixture 1=Elaeis guineensis kernel oil + essential oil of Ocimum gratissimum + sap of Jatropha multifidi; extract mixture $2=O$. gratissimum + sap extract of $J$. multifida) of $20 \%$ concentration were prepared and tested on eight Girolando cattle. Two different parts of the affected skin with acute lesions of dermatophilosis were debrided, and $0.5 \mathrm{~mL}$ of each of the extract mixture was applied per square centimeter of a single zone of the affected skin.

Results: Both extracts mixtures were found to possess significant wound healing properties compared to the control (procaine G penicillin). However, the extract mixture 1, which was made up of Elaeis guineensis kernel oil, essential oil of $O$. gratissimum and sap of J. multifida (Linn), showed a better result. This was evident by increase in the rate of wound contraction and healing without recurrence 2 weeks after the end of the experiment and the subsequent immediate manifestation of hair or hair growth at the affected area.

Conclusion: The preliminary findings of this study are very promising. Extract mixture 1 could serve as an alternative in the treatment or management of bovine dermatophilosis in Benin and other dermatophilosis endemic areas of the world. However, in vitro testing and sensitivity against isolated $D$. congolensis organism using extract mixture 1 as well as cost implications should be studied.
\end{abstract}

Keywords: farmer resilience, indigenous plants, plant extract, sustainable cattle breeding.

\section{Introduction}

The agricultural sector is one of the major economic drivers in Benin, contributing 22.6\% to the country's gross domestic product (GDP) [1]. It creates employment and food security for the teaming population; it also contributes to industrial and rural development. The production of livestock (cattle) is important in the agricultural sub-sector, and it contributes about $17.2 \%$ to the agricultural GDP in Benin [2]. Cattle are the major producers of animal protein $(58 \%)$ in the livestock sub-sector, followed by poultry $(21 \%)$, small ruminants $(13 \%)$, and pigs $(7 \%)[3,4]$.

As part of the revitalization plan of the agricultural sector in Benin by the government, efforts have

Copyright: Adoligbe, et al. Open Access. This article is distributed under the terms of the Creative Commons Attribution 4.0 International License (http://creativecommons.org/licenses/ by/4.0/), which permits unrestricted use, distribution, and reproduction in any medium, provided you give appropriate credit to the original author(s) and the source, provide a link to the Creative Commons license, and indicate if changes were made. The Creative Commons Public Domain Dedication waiver (http:// creativecommons.org/publicdomain/zero/1.0/) applies to the data made available in this article, unless otherwise stated. been put on-ground to boost the production of indigenous breeds through crossbreeding with high producing improved breeds of cattle. Therefore, Girolando dairy cattle known to be a crossbred product of Holstein and Gir, respectively, were imported from Brazil into the country to improve the milk production performance of local breeds of cattle in the country [5].

However, imported animals and their crossbred products from the temperate regions of the world, mostly find it difficult to favorably thrive in the African tropical region due to the hot and harsh environmental climate. Other challenges that militate against their production include attack by endemic infectious and contagious diseases, which include dermatophilosis among other devastating diseases.

The distribution of Bovine dermatophilosis is worldwide, but it is mostly recorded in tropical African countries, including Benin [6,7]. It is a tickborne disease caused by an actinomycetes bacterium, Dermatophilus congolensis, characterized by an exudative acute or chronic dermatitis that could be localized or generalized $[8,9]$. The lesions vary in size and 
severity, from small lesions (small paintbrush-like) and clear circumscribed scabs to more confluent progressive lesions. The disease results in gradual loss of body condition, decrease in milk and meat production, reduced working ability in draft animals, poor reproductive performance, decreased economic values of hide and skin, and losses due to mortality in weak animals [10]. In tropical areas, animals that recover from the wound caused by the disease were reported to be re-infected during the successive wet season, indicating the endemicity of the disease in the country [11]. It has been recorded that a wide variety of drugs are being administered with little or poor efficacy to the disease [12]. In addition, it has also been reported that the treatment and management of the disease using chemo-therapy or pharmaceutical intervention have not been productive in suppressing the severity of the lesions over the years [13], and it has been reported that disseminated lesions are generally refractory to therapy. In Benin, Ali-Emmanuel [14] showed that ointments made with the ethanolic extracts of leaves of Senna alata, Lantana camara, or Mitracarpus scaber, when applied once a day for 8-15 days, the effect of the mixture which stimulates the falling off of the crusts could start manifesting as early as by 3-4 days of application and the total healing of the disease could subsequently occur by 3-4 weeks after the end of the treatment. The selected ethnoveterinary phytogenetic extracts, which include Ocimum gratissimum, Jatropha multifida (Lin), and Elaeis guineensis (kernel oil), have been proven over the years to have antibacterial/anti-inflammatory properties [1517]. O. gratissimum leaves have been used in traditional medicine as a general tonic and in the treatment of diarrhea and conjunctivitis in humans [18]. The oil extracted from the leaf of $O$. gratissimum mixed with alcohol has been applied as a lotion against skin infections and has also been taken orally to treat bronchitis. The extract from the dry leaves, when boiled and administered orally, has been used to relieve headache and fever among other ethnomedicinal uses in humans [19]. The essential oil of this plant extract has a remarkable antibacterial effect, superior to those of commercial anti-septic pharmaceutical products when applied topically on the skin by humans [20]. It also regulates the nervous system, stimulates digestion and relieves osteoarthritis in humans. J. multifida (Linn) is locally called "five fingers plant" in Benin [21]. It is a plant of the Euphorbiaceae family with a widely recognized medicinal property. It was found to be helpful in the management and treatment of various diseases by nearly $80 \%$ of the human population in Africa, Asia, and Latin America [22]. J. multifida (Linn) is known over the years as one of the medicinal plants whose sap extract has been widely used for wound healing in Benin. Agban et al. [23] and Aiyelaagbe et al. [24], have previously reported the antibacterial effect of the leaves, stems, and roots extract of Jatropha multifida Linn. Indeed, E. guineensis (kernel oil) extract has been used over the years in Nigeria in the treatment and management of various skin diseases and infections in both humans and animals [25].

The study aimed to assess the therapeutic efficacy of different mixtures prepared with indigenous phytogenetic extracts from Benin in the management and treatment of Girolando cattle that showed high sensitivity to the disease compared to any other known cattle breed in Benin.

\section{Materials and Methods}

\section{Ethical approval}

The plant products used in this study were common traditional medicinal plants that are widely used in the management and treatment of some common human ailments in Benin without any formal government regulation. For this reason, this study was conducted in complete agreement with the Benin national veterinary and pharmaceutical regulations. Therefore, no ethical approval was necessary.

\section{Study period and location}

The study was conducted during September and October 2020. The experimental study was carried out in a semi-intensive ruminant farm located in the municipal area of Abomey-Calavi, Department of Atlantic, Benin. Abomey-Calavi area is characterized by a sub-equatorial climate of four seasons that alternates two rainy seasons and two dry seasons. The two rainy seasons run from March to July and from September to November, respectively, while the dry seasons extend from July to September and from December to March, respectively. The average temperature in Benin is between 28 and $29^{\circ} \mathrm{C}$, with rainfall ranging from 1100 to $1300 \mathrm{~mm}$. The geographical aerial view shows Plateaus dominating the entire region with a maximum altitude of $31 \mathrm{~m}$ above sea level. Agriculturally, the vegetation is heterogeneous in nature, characterized by savannah shrubs, tropical short trees, and lush grass cover [26].

\section{Animals}

Nine Girolando cattle presenting acute lesions of dermatophilosis as described previously $[12,14]$ were used in the experiment (Figure-1). To circumvent the influence of external factors, the animals were not allowed to pasture outside the paddock during the trial. They were fed in the cowshed and routine farm prophylaxis was strictly followed.

\section{Essential oil extract of 0 . gratissimum}

The essential oil extract of $O$. gratissimum was obtained by hydro-distillation [27] from the leaves of $O$. gratissimum harvested during the month of September near Abomey-Calavi. The plant was identified and authenticated by Dr. Yedomonhan H. from the National Herbarium of the University of AbomeyCalavi. Voucher specimens were deposited in the National Herbarium of the University of AbomeyCalavi in the Republic of Benin under the number (YH640/HNB). The harvested leaves were dried for 

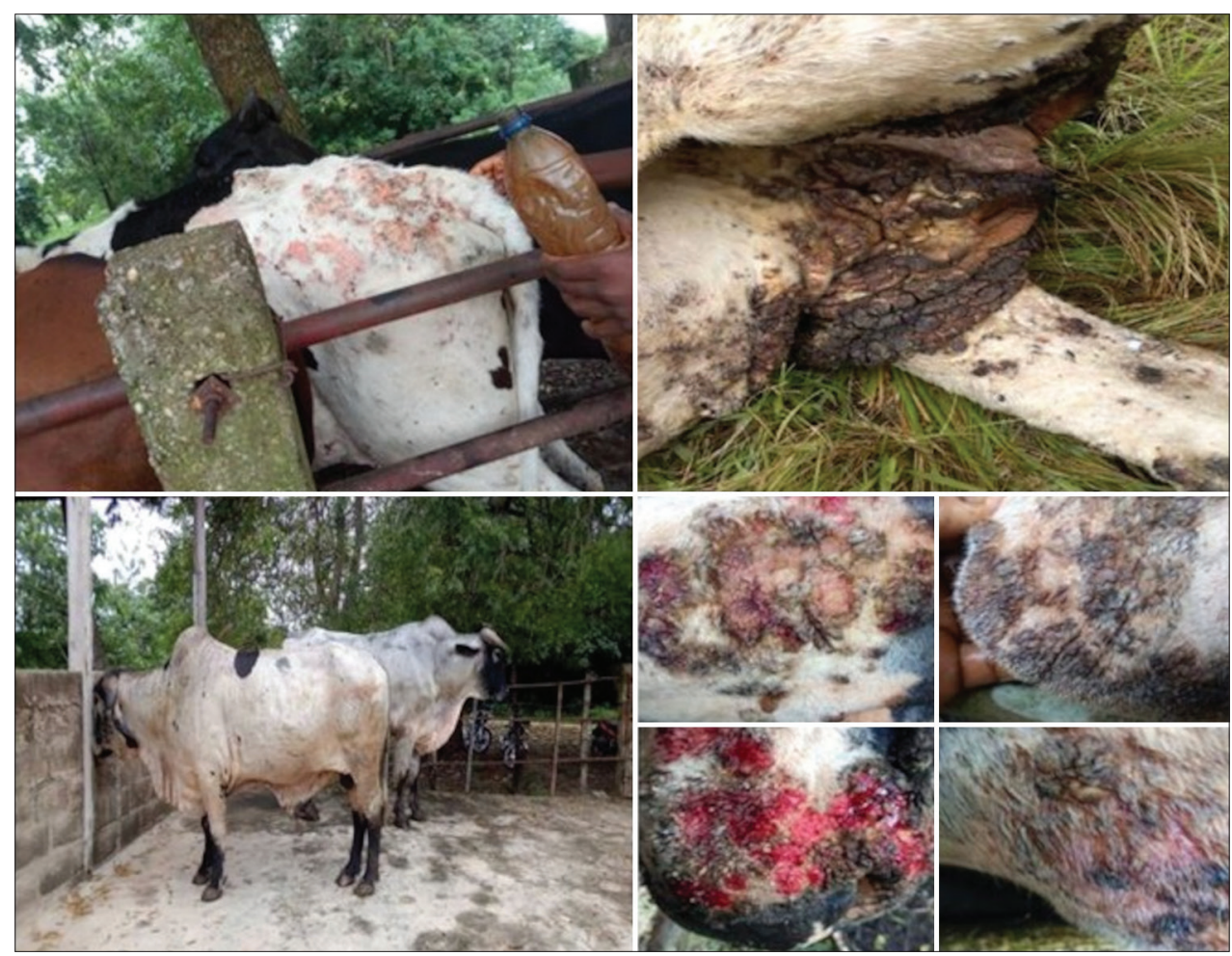

Figure-1: A live Girolando cattle and dermathophilosis lesions.

3 days under a shade area and the oil was extracted at the Applied Chemistry Research Laboratory of the University of Abomey-Calavi using a Clevenger extraction apparatus (MH1201, Maihun, Jiangsu, China). The leaves were put in a flask containing boiled $\left(100^{\circ} \mathrm{C}\right)$ water. The vapor rises in the assembly of the flask to a condensed level, and then the condensate in liquid form was allowed to freely drip into a small beaker. The oil extract eventually floats on the liquid and was gradually returned to the heated flask through the diagonal conduit. After $2 \mathrm{~h}$ of extraction, the volume of the oil extract collected in the burette was directly measured and then stored in the refrigerator at $4{ }^{\circ} \mathrm{C}$ during the experimentation time.

\section{Sap extract of $\boldsymbol{J}$. multifida (Linn)}

The sap extract of J. multifida (Linn) was collected from a fresh Linn stem during the month of September 2019 in the municipal areas of Abomey-Calavi and Allada. The plant was identified and authenticated by Dr. Yedomonhan H. from the National Herbarium of the University of Abomey Calavi. Voucher specimens were deposited in the National Herbarium of the University of Abomey-Calavi in the Republic of Benin under the number (YH639/HNB). The extract was carefully collected directly into the Eppendorf tubes after cutting the stem while taking care to avoid external contamination [17]. The harvested samples were kept at $4{ }^{\circ} \mathrm{C}$ in the refrigerator during the experimentation time.

\section{Oil extracts of $E$. guineensis (kernel oil)}

Raw black E. guineensis (kernel oil) extract was purchased from the market and filtered to remove palm nut residue.
Determination of the optimal concentration of the mixture component

To determine the optimal concentration of the products to be mixed, eight zones of $5 \mathrm{~cm}^{2}$ of infected areas were each debrided on the infected skin of the sick animals and different concentrations of the products were tested. $0.5 \mathrm{~mL}$ of each of the extracted products was applied independently per square centimeter of the infected areas. The application of the different extracts was carried out in every 2 days' interval for 10 consecutive days. At the end of the pre-experimental phase, $20 \%$ concentration of each of the extracts turned out to be the most efficacious for each of the solutions and was thereafter retained for application for the rest of the experiment (Table-1).

\section{Mixture preparation}

During the combination procedure, two extracts mixtures were prepared based on the selected phytogenetic extracts and were tested on the lesions of the dermatophilosis infected animals (Table-2). These include the mixture of equal volume $(33 \mathrm{~mL})$ of essential oil extract of $O$. gratissimum, sap extract of $J$. multifida (Linn) and raw black E. guineensis (kernel oil) extract (Extract mixture 1) and mixture of half volume $(50 \mathrm{~mL})$ of essential oil extract of $O$. gratissimum and sap extract of $J$. multifida (Linn) (Extract mixture 2).

\section{Mixture application}

The efficacy of the mix or combined extracts was tested on 8 out of 9 selected animals; two affected zones on the skin presenting crusty lesions were debrided. Each of the extract mixtures $(2.5 \mathrm{~mL})$ was applied to a specific infected zone $\left(5 \mathrm{~cm}^{2}\right)$ on each of the animals every $48 \mathrm{~h}$ for 19 consecutive days. The hard crusts 
Table-1: Optimal concentration determination for each product.

\begin{tabular}{|c|c|c|c|c|}
\hline Zone & Phytogenetic resources/extracts & Concentration (\%) & Quantity (mL) & Application area $\left(\mathrm{cm}^{2}\right)$ \\
\hline 1 & Acetone (additive acting as an emulsifier) & & 2.5 & 5 \\
\hline 2 & PKO & & 2.5 & 5 \\
\hline 3 & EOOG & 5 & 2.5 & 5 \\
\hline 4 & EOOG & 10 & 2.5 & 5 \\
\hline 5 & EOOG & 20 & 2.5 & 5 \\
\hline 6 & SJML & 5 & 2.5 & 5 \\
\hline 7 & SJML & 10 & 2.5 & 5 \\
\hline 8 & SJML & 20 & 2.5 & 5 \\
\hline 9 & Negative control & & & 5 \\
\hline
\end{tabular}

EOOG=Essential oil extract of Ocimum gratissimum, SJML=Sap extract of Jatropha multifida Linn, PKO=Elaeis guineensis kernel extract.

Table-2: Mixture preparation of phytogenetic extracts for the treatment of dermatophilosis infected animals.

\begin{tabular}{lccc}
\hline Products & EOOG (20\%) & SJM (20\%) & PKO \\
\hline Mixtures & & & \\
Extract mixture 1 & $33.33 \%$ & $33.33 \%$ & $33.33 \%$ \\
Extract mixture 2 & $50 \%$ & $50 \%$ & $0 \%$ \\
\hline
\end{tabular}

EOOG = Essential oil extract of Ocimum gratissimum, $\mathrm{SJML}=$ Sap extract of Jatropha multifida Linn, PKO=Elaeis guineensis kernel extract.

were removed from all the infected zones before the application of the extracts mix. The ninth animal was used as a control and was receiving the medication used on the farm previously (Intramuscular injection of penicillin $\mathrm{G}$ procaine every 2 days at a dosage of $1 \mathrm{~mL} / 20 \mathrm{~kg}$ body weight). Four infected zones on the skin presenting crusty lesions of dermatophilosis were debrided on the control animal to assess the wound healing progress.

\section{Wound healing assessment}

The progress of the wound healing over the period of the experiment was used as an indicator to assess the therapeutic efficacy of each of the mixtures compared to the control in the treatment of dermatophilosis on the cattle used for the experiment. The infected wound areas on the skin were measured by tracing the wound margin using a tape measured on day 1 of the experiment and subsequently on every 2 days until day 19. The healed areas were calculated by subtracting the real-time wound area from the original wound area. The percentages of wound contraction were calculated using the formula: Percentage of wound contraction $=($ Healed area/Total wound area $)$ [28]. The average percentage of wound contraction induced by each of the mixtures was obtained by dividing 8 by the sum of the percentage of wound contraction obtained from each of the respective extract mixture application zones. The average percentage of wound contraction induced by penicillin $G$ procaine was obtained by dividing the sum of the percentage of wound contraction obtained from each of the four targeted zones.

\section{Statistical analysis}

Data are expressed as mean \pm standard deviation. Results were analyzed by the Generalized Linear
Models (Proc GLM) procedure followed by Student's t-test using statistical analysis system software R version 3.5.1 (R Foundation for Statistical Computing, Vienna, Austria) [29].

\section{Results \\ Wound contraction progress}

The progress of wound contraction in each group over the experimental time is shown in Figure-2 and Table-3. Overall, we observed a progressive positive trend of average wound contraction during all the days of the experiment. However, statistically significant average wound contraction was exhibited among groups from day 9 to day 19 (Table-3). Average wound contraction was significantly better in Group 1 than the control group from day 7 to day $13(p<0.05)$, and very significantly better in Group 1 than the control group and Group 2 from day 15 to day $19(\mathrm{p}<0.01)$. As shown in Figure-2, hairs start growing on the treated areas, which eventually healed with few scarring on day 17 (Extract mixture 1).

\section{Discussion}

Dermatophilosis in cattle is characterized by exudative dermatitis with scab formation. The previous scholars have shown that ethnoveterinary approaches are preferred in wound healing or cure of the disease since they are devoid of side effects and are more effective [30,31]. The present study aims at mixing or diluting different phytogenetic extracts with proven records of antibacterial/anti-inflammatory activity in both humans and animals. These phytogenetic extracts include; essential oil extract of O. gratissimum, sap extract of J. multifida (Linn), and raw black Palm kernel extract for topical treatment of bovine dermatophilosis lesions in Benin. The outcome of our findings indicated that each of the tested extract mixtures has a wound-healing capability, but at a different rate with extract mixture 1 , which contains (3 phytogenetic extracts) that are considered the most efficacious substance against bovine dermatophilosis. This variation in wound healing effect could probably be due to the different chemical components of each of these phytogenetic extracts.

It has been previously stipulated that oxidative stress has been associated with most acute and chronic 
Table-3: Average percentage of wound contraction at various experimental days.

\begin{tabular}{lcccc}
\hline Time (Day) & \multicolumn{3}{c}{ Experimental Groups } & p-value \\
\cline { 2 - 4 } & Control & Group 1 & Group 2 & \\
\hline 3 & $18.06 \pm 6.49 a$ & $31.59 \pm 3.31 \mathrm{a}$ & $31.47 \pm 6.51 \mathrm{a}$ & 0.1068 \\
5 & $16.79 \pm 5.40 \mathrm{a}$ & $24.84 \pm 15.28 \mathrm{a}$ & $31.47 \pm 6.51 \mathrm{a}$ & 0.09251 \\
7 & $22.74 \pm 3.94 \mathrm{a}$ & $34.84 \pm 12.62 \mathrm{a}$ & $39.86 \pm 15.30 \mathrm{a}$ & 0.09213 \\
9 & $29.86 \pm 4.26 \mathrm{~b}$ & $57.51 \pm 5.85 \mathrm{a}$ & $50.85 \pm 4.91 \mathrm{a}$ & 0.01089 \\
11 & $30.67 \pm 4.24 \mathrm{~b}$ & $64.82 \pm 5.69 \mathrm{a}$ & $54.24 \pm 5.38 \mathrm{a}$ & 0.002191 \\
13 & $34.38 \pm 2.37 \mathrm{~b}$ & $68.40 \pm 7.82 \mathrm{a}$ & $54.32 \pm 5.42 \mathrm{a}$ & 0.003773 \\
15 & $41.55 \pm 1.29 \mathrm{c}$ & $87.71 \pm 1.81 \mathrm{a}$ & $59.74 \pm 9.96 \mathrm{ab}$ & 0.0001875 \\
17 & $47.51 \pm 2.46 \mathrm{c}$ & $100 \pm 0.18 \mathrm{a}$ & $65.61 \pm 3.36 \mathrm{~b}$ & 0.0003338 \\
19 & $53.07 \pm 15.38 \mathrm{c}$ & $100 \pm 018 \mathrm{a}$ & $72.75 \pm 3.13 \mathrm{~b}$ & 0.0006247 \\
\hline
\end{tabular}

Group 1: Zones treated with extract mixture 1 (EOOG+SJML+PKO), Group 2: Zone treated with extract mixture 2 $(E O O G+S J M L) ;$ Mean+standard deviation within rows with different letters are significantly $(p<0.05, p<0.01$ or $p<0.001)$ different according to Student's t-test

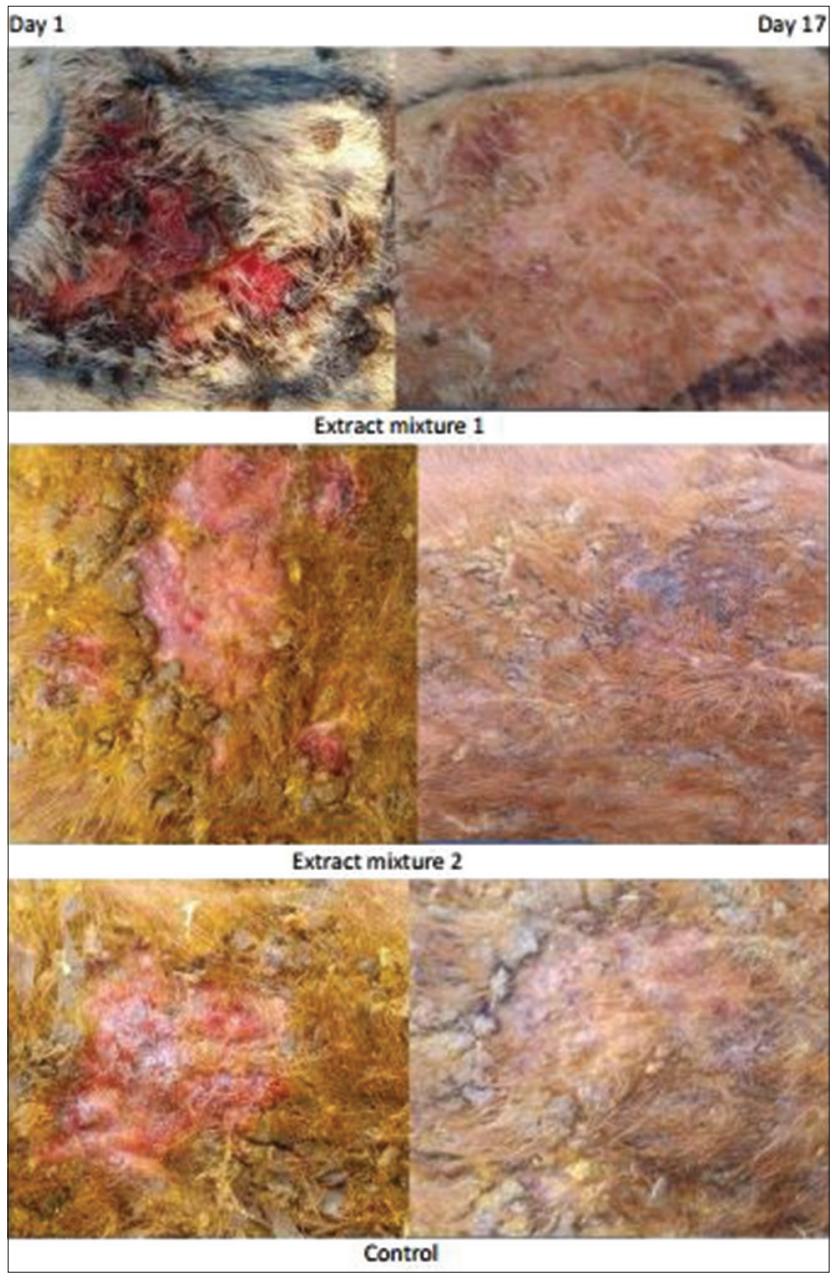

Figure-2: Wound healing progress of dermathophilosis over experimental time with the application of different mixtures.

inflammatory conditions such as wound healing, but specifically, flavonoid component of the plant extracts was also known to be responsible for free radical scavenging, which is important in wound healing [28]. The previous study that was conducted in southern Benin on the chemical profile of the sap extract of $J$. multifida (Linn) revealed the presence of flavonoids, tannins, and terpenes groups [32]. Many scholars have previously proved the wound healing activity of these chemical compounds. For instance, Sheeba et al., [33] and
Mondal and Suresh [34] have previously reported that flavonoids and tannins were present in Cleome rutidosperma' roots and Cassia occidentalisa leaves, and they observed healing of experimentally induced wounds in rats. Besides, the antioxidant and antimicrobial activities of flavonoids contained in the sap extract of J. multifida (Linn) have also been reported $[23,35,36]$.

The previous analysis of essential oil extract produced from the two common types of $O$. gratissimum grown in Benin has shown the presence of three main components, which includes thymol, p-cymene, and $\gamma$-Terpinene, though; their concentration may vary under the influence of different factors [37]. The antimicrobial, anti-inflammatory, and rapid wound healing activities of the essential oil extract of $O$. gratissimum have been previously attributed to the presence of these components $[15,38]$.

On the other hand, E. guineensis (kernel oil) extract is also commonly known to be used in SouthEastern Nigerian communities over the years to treat various skin diseases in humans and animals [25]. Mboui [16] reported that the mineral components of E. guineensis (kernel oil), particularly zinc, induced complete wound healing after 2 weeks of daily application.

We then strongly believe that based on the outcome of our findings, the following stated rationale was behind the assumptions that suggest plant products give better results than chemotherapeutic agents in wound healing [39]. In addition, Klotoé et al. [32] have also previously reported a complete wound healing activity of the sap extract of J. multifida (Linn) in rats and grass-cutter after 18 and 19 days of treatment, respectively. Ointments made with the ethanolic extracts of leaves of $S$. alata, L. camara, and $M$. scaber have also been used as topical treatments on chronic crusty or acute lesions of dermatophilosis with very good results [14]. Consequently, based on the outcome of their findings, the ointments used in their experiment practically stimulate the detachment and falling off of the crusts after 3-4 days of treatment when applied once a day for 8-15 days [14]. Hair production and growth then commence immediately on 
the treated side, which heals without scarring within 3-4 weeks after the end of the treatment. In this preliminary experimental trial, the plant extracts mixture application was performed every 2 days, and complete wound healing was attained on the $17^{\text {th }}$ day of treatment. The results obtained were almost conclusive and could even be much better if the extract mixture application was performed on a daily basis.

\section{Conclusion}

As a preliminary study, the findings of this present study demonstrate that a mixture of essential oil extract of $O$. gratissimum, sap extract of $J$. multifida (Linn), and raw black E. guineensis (kernel oil) extract promotes skin wound healing activity in cattle and therefore constitute an alternative remedy for bovine dermatophilosis lesion treatment. We, therefore, recommend further study such as in vitro testing and sensitivity against isolated $D$. congolensis organism using extract mixture 1 be conducted to comprehend the complete wound healing mechanism of the extract mixture and that cost implications be assessed.

\section{Authors' Contributions}

CA: Designed the study, drafted, critically revised the manuscript, and collected samples. RG: Designed and managed the study, and wrote the manuscript. JA: Participated in the design of the study and interpretation of the data. SM: Revised and edited the manuscript. SF: Revised and approved the final manuscript. All authors read and approved the final manuscript.

\section{Acknowledgments}

The authors would like to thank the staff of ATADJE animal farm for their kind help with data collection. The authors did not receive any funds for this study.

\section{Competing Interests} interests

The authors declare that they have no competing

\section{Publisher's Note}

Veterinary World remains neutral with regard to jurisdictional claims in published institutional affiliation.

\section{References}

1. WB. (2018) World Development Indicators. Agriculture, Forestry, and Fishing, Value Added (\% of GDP). Available from: https://data.worldbank.org/indicator/NV.AGR. TOTL.ZS Retrieved on 07-06-2020.

2. Countrystat. (2018) Élevage: Total des Effectifs D'animaux Vivants par Année. Niveau Administratif 2, Produits. Available from: http://www.countrystat.org/home.aspx$? \mathrm{c}=$ ben $\&$ ta $=053$ SPD $135 \&$ tr- 2 Retrieved on 10-09-2020.

3. DSA. (2017) Direction des Statistiques Agricoles. Les Statistiques Agricoles du Bénin. p100.

4. Food and Agriculture Organization. (2015) Organisation des Nations-Unis pour l'Agriculture et l'Alimentation. Secteur Avicole Bénin. Revues Nationales de l'élevage de la Division de la Production et de la Santé Animales de la FAO. Paper No. 10. Food and Agriculture Organization, Rome.

5. Alassane, Y., Ahounou, S.G., Toleba, S.S., Adjakpa, A.A., Dotche, I.O., Houaga, I., Moula, N., Antoine-Moussiaux, N., Hornick, J.L. and Youssao, A.K. (2018) Zootechnical performance of girolando cattle at kpinnou Breeding Farm, South-West of Benin Republic. J. Adv. Vet. Anim. Res., 5(2): 123-130.

6. Ndhlovu, D. and Masika, P. (2016) Bovine dermatophilosis: Awareness, perceptions and attitudes in the small-holder sector of north-west Zimbabwe. Onderstepoort J. Vet. Res., 83(1): 1004

7. Noudèkè, N.D., Dossou-Gbété, G., Pomalégni, C., Mensah, S., Aplogan, L.G., Atchadé, G., Dougnon, J., Youssao, I., Mensah, G.A. and Farougou, S. (2017) Prevalence of Bovine Brucellosis, Tuberculosis and Dermatophilosis among Cattle from Benin's Main Dairy Basin. J. Vet. Med. Anim. Health, 9(5): 97-104.

8. Aliye, S., Fesseha, H. and Kifle, T. (2020) Dermatophilosis in farm animals and its status in Ethiopia: A review. Int. J. Pharm. Biomed. Res., 7(1): 27-39.

9. Olaogun, S.C. and Onwuzuruike, K.J. (2018) Incidence and biochemical parameters of dermatophilosis in Nigerian cattle breeds from livestock markets, Oyo state, Nigeria. Open Vet. J., 8(1): 35-39.

10. Dalis, J.S., Kazeem, H.M., Makinde, A.A. and Fatihu, M.Y. (2007) Agalactia due to severe generalized dermatophilosis in a white Fulani cow in Zaria, Nigeria. Vom J. Vet. Sci., 1(4): 56-58.

11. Ojong, B.W., Sacca, E., Bessong, P. and Plasentier, E. (2016) Prevalence of bovine dermatophilosis and disease-associated alleles in zebu Goudali cattle and their Italian Simmental crosses ranching in the western highland plateau savannah of Cameroon. Trop. Anim. Health Prod., 48(7): 1329-1335.

12. Burd, E.M., Juzych, L.A., Rudrik, J.T. and Habib, F. (2007) Pustular dermatitis caused by Dermatophilus congolensis. J. Clin. Microbiol., 45(5): 1655-1658.

13. Quinn, P.J., Markey, B.K., Carter, M.E., Donnely, W.J. and Leonard, F.C. (2011) Microbiologia Veterinária e Doenças Infecciosas. Artmed, Porto Alegre. p196-206.

14. Ali-Emmanuel, N. (2003) Dermatophylose bovine en République du Bénin: épidémiologie, chimiothérapie et phytothérapie comparée. J. Ethnopharmacol., 86(2-3): 167-171.

15. Orafidiya, L., Agbani, E., Oyedele, A., Babalola, O. and Onayemi, O. (2002) Preliminary clinical tests on topical preparations of Ocimum gratissimum Linn leaf essential oil for the treatment of Acne vulgaris. Clin. Drug Investig., 22(5): 313-319.

16. Mboui, O.S. (2003) Traditional Palm Kernel Oil, State Doctorate Thesis, Faculty of Medicine, Pharmacy and Odontostomatology, Cheikh Anta-Diop University, Dakar.

17. Klotoé, J.R., Dougnon, T.V., Dougnon, T.J., Agbodjento, E., Atègbo, J.M. and Loko, F. (2014) Jatropha multifidi Lin (Euphorbiaceae): Exploration des propriétés antibactériennes et du pouvoir cicatrisant de la sève de cette plante chez le rat albinos de Souche Wistar. Rev. Microbiol. Ind. Sanit. Environ., 8: 120-132.

18. Emeka I.N. and Elizabeth E.E. (2009) Justification for the use of Ocimum gratissimum $\mathrm{L}$ in herbal medicine and its interaction with disc antibiotics. BMC Complement. Altern. Med., 9(1): 37

19. Iwu, M.M. (1993) Handbook of African Medicinal Plants. CRC Press Inc., Boca Raton, Floridamm. p183-184.

20. Nwinyi, O.C., Chinedu, N.S., Ajani, O.O., Ogunniran, K.O., Ikpo, C.O. and Ogunniran, K.O. (2009) Antibacterial effects of extracts of Ocimum gratissimum and Piper guineense on Escherichia coli and Staphylococcus aureus. Afr. J. Food Sci., 3(3): 77-81.

21. de Souza, S. (1988) La Flore du Bénin, Tome. $3^{\text {rd }}$ ed. Presse 
de Notre Dame, Cotonou, Bénin. p394.

22. Aiyelaagbe O. (2001) Antibacterial activity of Jatropha multifida roots. Fitoterapia, 72(5): 544-546.

23. Agban, A., Yao, H., Pissang, P., Tchacondo, T. and Batawila, K. (2020) Evaluation du potentiel antimicrobien et de la toxicité des extraits de Jatropha multifida Linn, (Euphorbiaceae). J. Appl. Biosci., 151: 15550-15558.

24. Aiyelaagbe, O., Oguntuase, B.J., Babatunde, D., Arimah, A. and Bola, A. (2008) The antimicrobial activity of Jatropha multifida extracts and chromatographic fractions against sexually transmitted infections. J. Med. Sci., 8(2): 143-147.

25. Owoyele, B.V. and Owolabi, G.O. (2014) Traditional oil palm (Elaeis guineensis jacq.) and its medicinal uses: A review. Hum. Med., 4(3): 161-168.

26. Gbesso, G.H.F., Logbo, J., Lougbegnon, O.T., Tente, B. and Codjia, J.T.C. (2018) Diversité floristique des groupements végétaux spontanés dans la commune d'Abomey-calavi au Bénin. Rev. Bio Ressour., 8(1): 1-12.

27. Hesham, H.A., Rassem, A.H.N. and Rosli, M.Y. (2016) Techniques for extraction of essential oils from plants: A review. Aust. J. Basic Appl. Sci., 10(16): 117-127.

28. Kumari, M., Eesha, B.R., Amberkar, M., Babu, S., Rajshekar and Kumar, N. (2010) Wound healing activity of aqueous extract of Crotalaria verrucosa in Wistar albino rats. Asian Pac. J. Trop. Med., 3(10): 783-787.

29. R Core Team. (2016) A Language and Environment for Statistical Computing. R Foundation for Statistical Computing, Vienna, Austria.

30. Toyang, J.N., Wanyama, J., Nuwanyakpa, M. and Django, S. (2007) Ethnoveterinary Medicine a Practical Approach to the Treatment of Cattle Diseases in Sub-Saharan Africa. Agromisa Foundation and CTA, Wageningen, Digigrafi, ISBN Agromisa.

31. Syakalima, M., Simuunza, M. and Zulu, V.C. (2018) Ethnoveterinary treatments for common cattle diseases in four districts of the Southern Province, Zambia. Vet. World,
11(2): 141-145.

32. Dougnon, T.V., Klotoé, J.R., Dougnon, T.J., Sègbo, J., Atègbo, J.M., Edorh, P.A., Sodipo, O., Dougnon, F., Dandjesso, C., Loko, F. and Dramane, K.(2012) Hemostatic activity screening and skin toxicity of sap of Jatropha multifidi L. (Euphorbiaceae) used in traditional medicine. Asian Pac. J. Trop. Dis., 2(2): S927-S932.

33. Sheeba, M., Emmanuel, S., Revathi, K. and Ignacimuthu, S. (2009) Wound healing activity of Cassia occidentalis L. in albino Wistar rats. Int. J. Integr. Biol., 8(1): 1-6.

34. Mondal, S. and Suresh, P. (2012) Wound healing activity of Cleome rutidosperma DC Roots. Int. Curr. Pharm. J., 1(6): $151-154$

35. de Carvalho, C., Mariano, L.V., Negrão, V., Gonçalves, P.C. and Marcucci, M.C. (2018) Phenols, flavonoids and antioxidant activity of Jatropha multifida L. collected in Pindamonhangaba, Sao Paulo State, Brazil. J. Anal. Pharm. Res., 7(5): 581-584.

36. Anani, K., Adjrah, Y., Améyapoh, Y., Karou, S.D., Agbonon, A., de Souza, C., Gbeassor, M. (2016) Antimicrobial, anti-inflammatory and antioxidant activities of Jatropha multifida L. (Euphorbiaceae). Pharmacogn. Res., 8(2): 142-146.

37. Yayi, E., Gbenou, J.D., Ahoussi, L.A., Moudachirou, M. and Chalchat, J.C. (2004) Ocimum gratissimum L., siège de variations chimiques complexes au cours du développement. C. R. Chim., 7(10-11): 1013-1018.

38. Orafidiya, L.O., Agbani, E.O., Iwalewa, E.O., Adelusola, K.A. and Oyedapo, O.O. (2004) Studies on the acute and sub-chronic toxicity of the essential oil of Ocimum gratissimum L. leaf. Phytomedecine, 11(1): 71-76.

39. Phillipe, M.A.B., Tobada, P., Aboh, A.B., Pomalegni, S.C.B., Mensah, S.E.P., Kpera, G.N., Farougou, S. and Mensah, G.A. (2012) Wound healing activity of Jatropha multifidi in domestic grass cutter(Thryonnomys swinderanius). Bull. Rec. Agron. Benin, p1840-7099. 